\title{
Implementation of Covid-19 on Character Education
}

\author{
Suwarno, Durhan, Muhaimin \\ IAIN Takengon, Indonesia \\ Fakultas Tarbiyah INSTIKA Guluk-Guluk Sumenep Madura, Indonesia \\ Kemenag Mojokerto, Indonesia \\ Email: suwarno0963@yahoo.com,durhan.ariev@gmail.com,muhaiminsulkan12@gmail.com
}

\begin{tabular}{|c|c|}
\hline ARTICLE INFO & ABSTRACT \\
\hline $\begin{array}{l}\text { Date received : } 01 \text { April } 2021 \\
\text { Revision date : } 04 \text { March } 2021 \\
\text { Date received : } 16 \text { May } 2021\end{array}$ & $\begin{array}{l}\text { Corona Virus Disease } 2019 \text { or known as COVID-19 outbreak } \\
\text { was first discovered in Wuhan, China in December } 2019 \text { and } \\
\text { then designated as a pandemic by WHO on March } 11,2020 \text {. } \\
\text { This study uses the method of literature research or literature }\end{array}$ \\
\hline $\begin{array}{l}\text { Keywords: } \\
\text { Strategy } \\
\text { Universe War } \\
\text { Political Integration } \\
\text { Unity }\end{array}$ & $\begin{array}{l}\text { studies. To successfully administer character education during } \\
\text { the COVID- } 19 \text { epidemic, close cooperation between parents, } \\
\text { educators (teachers), the community, and government } \\
\text { (education units) is required. }\end{array}$ \\
\hline
\end{tabular}

\section{INTRODUCTION}

Corona Virus Disease 2019 or known as COVID-19 outbreak was first discovered in Wuhan, China in December 2019 and then designated as a pandemic by WHO on March 11, 2020 (WHO, 2020). Wabah ini menyebar dengan sangat cepat dan infect almost all countries and regions of the world. Since the announcement of the COVID-19 outbreak as a pandemic in mid-March 2020, the number of confirmed cases has increased rapidly every day around the world. Therefore, every country's top priority is to suppress the spread of the virus and minimize its impact on society (Osman, 2020). Efforts are being made across the country to minimize the spread of COVID-19 and its impacts. Generally, the policies implemented by almost all countries in the world are centered on two main policies, namely, social distancing and lockdown. (Herdiana, 2020). The policy proved able to flatten the curve and control the transmission of the virus (Sintema, 2020).

Indonesia as one of the countries exposed to COVID-19 also implemented a similar policy. Since the first case of COVID19 was confirmed on March 2, 2020 in Depok, West Java the number of positive cases continues to grow quite quickly. As of June 2020 there were 31,186 confirmed cases with 1851 deaths in Indonesia and counting over time. Even to date Monday (26/04) there are 1.6 million confirmed positive cases in Indonesia. (Gugus Tugas COVID-19, 2021). Various efforts have been made by the government in order to reduce, control and mitigate the spread of the COVID-19 outbreak by implementing the following policies: (1) Stay at Home; (2) Social and Physical Distancing restrictions; (3) Use of personal protective equipment (masks); (4) Keeping yourself clean (Washing hands); (5) Applying sneezing and coughing etiquette; (6) Work/Study From Home; (7) Postpone all activities that gather crowds; (8) Procurement of COVID-19 tests (swab test or rapid test); (9) increase hospital capacity, especially COVID-19 referral hospitals; (10) establish a national COVID-19 emergency team and (11) Large-Scale Social Restrictions (Nugraha et al., 2020; Tuwu, 2020).

(PSBB)

The COVID-19 outbreak has had a mixed global impact on almost all sectors of people's lives, particularly in the health, economy and education sectors. (Osman, 2020). Education is a pillar in the development of every country, so education becomes the main thing in the development and development of all countries in the world. The United Nations Education, Scientific and Cultural Organization (UNESCO) said that the COVID-19 pandemic has a huge impact on

\begin{tabular}{ll}
\hline How to cite: & $\begin{array}{l}\text { Suwarno. (2021) Implementation of Covid-19 on Character Education, 2(3). } \\
\text { https://doi.org/10.46799/jsss.v2i3.133 }\end{array}$ \\
\hline E-ISSN: & $2721-5202$ \\
\hline Published by: & Ridwan Institute \\
\hline
\end{tabular}


the world's education system, with each country facing challenges ranging from changing the education curriculum to closing the education system to avoid the spread of the virus. (Owusu-Fordjour et al., 2020; UNESCO, 2020). This is happening in all countries around the world including Indonesia which makes the government and related agencies must present alternatives to the progress of the education system (Abidah et al., 2020). The closure of educational institutions proved to be an efficient way to minimize the spread of the virus despite posing many challenges for students, faculty, families and the community (Aslam, 2020; Owusu-Fordjour et al., 2020). As a result of social distancing policy, the government through the Ministry of Education and Culture (Kemendikbud) applies the policy of Learning from Home (BDR) or Distance Learning (PJJ). In this policy all learning is done online or offline or combined both in accordance with the availability and readiness of facilities and infrastructure. (SE Kemendikbud No 15/2020). Minister of Education and Culture, Nadim Makarim through Circular Letter No. 4 of 2020 on the Implementation of Education In the Emergency Period of Corona Virus Disease (Covid-19) emphasizes that the principle of distance learning is to provide a meaningful learning experience for students without being burdened with demands to complete all curriculum achievements.

Education as stated in the UU RI No 20 Tahun 2003 merupakan usaha sadar dan terencana untuk realizing the atmosphere of learning and learning process so that learners can actively develop the potential of didrinya to have religious spiritual power, self-control, personality, intelligence, noble morals, as well as the necessary skills themselves, society, nation, and country (Depdiknas, 2003). Entering the era of industrial revolution 4.0 where technological advances can very rapidly result in adverse impacts such as the development of individualist values, hedonists, materialistics and so on. If left unchecked, the values of the nation's personality will be further eroded, so there needs to be planting and strengthening the character of the nation. In addition, moral degradation has now occurred in almost all walks of life including learners. This can be seen from the number of criminal cases, violence, drugs to corruption. Character education is expected to have a good impact on the progress of people's lives, nations and countries so as to form a moral and qualified generation. (Santika, 2020). The enactment of PJJ policy as an effort by the government to keep education in Indonesia running brings extra duties and responsibilities for teachers, parents and related parties. In this era of the COVID-19 pandemic, teachers are challenged to be able to create a learning environment that can develop the ethics, responsibilities and character of students. On the other hand, since the enactment of PJJ there are many obstacles faced by both students, teachers and educational institutions that cause hampered learning process. (Jahroh \& Sutarna, 2016; Santika, 2020; Sari et al., 2020). In the current situation of the COVID19 pandemic, where learning is conducted online which makes the role of teachers limited, students are required to be independent in learning. Therefore, it is necessary to continue to integrate character education in online learning. The goal is for the character of learners to develop, be able to independently increase knowledge and develop their potential, and be able to apply it in social life. (Intania, 2020).

Based on these issues, this study will provide ideas on the implementation of Character Education during the COVID-19 pandemic and strategies that can be implemented.

\section{METHOD}

This research uses the method of literature research or literature studies. Literature research is a research that takes data sources from various literature such as books, journals, documents, dictionaries, newspapers and so on. This type of research is a multi-case study using qualitative approach. Qualitative research is used to examine the condition of natural objects, where researchers are as a key instrument, data collection techniques are carried out triangulated (combined), data analysis is inductive or qualitative (Sugiyono, 2013). Meanwhile, multi-case studies are researches that aim to intensively study specific social units that include individuals, groups, institutions and communities (Suryabrata, 1998). The main kazracteristic of multistym studies is the research of two or more subjects, background or place of data 
storage. In this study, the case studied was the implementation of character education in the era of the COVID-19 pandemic in three regions, namely Central Aceh, Ngawi, and Mojokerto districts.

\section{RESULTS AND DISCUSSION}

1) Impact of covid on education

School closures as a result of social distancing policies tend to increase pressure on students, teachers, and parents, especially those with limited digital skills and limited resources to continue their education. It also adds to the burden on parents because they not only struggle to meet the needs of the household, but also have to do supervisory tasks to ensure their children learn from home. School closures can have a negative impact on academic interests and student performance. If students are not productively involved in the learning process, then it can lead to laziness that will lead to loss of learning interest, declining academic achievement, dropouts and even the involvement of adolescents in crime (Onyema et al., 2020). According to Quentin (2014) school closures will have an impact on academic prestatsation especially for students with special needs or those who have learning difficulties and need more physical attention and guidance from teachers. While technology can be used to correct some of the impacts of school closures, it is still unable to replace the important effects of face-to-face interaction of students and teachers.

According to (UNESCO, 2020b) some of the harmful impacts of school closures due to the COVID-19 outbreak are as follows: (1) The disrupted learning process, in which the school provides essential basic learning and when closed, students lose the opportunity to grow and develop; (2) Nutrition, where many students rely on free or discounted meals provided at school for healthy food and nutrition; (3) Gaps in accessing digital learning portals, lack of access to technology or good internet connectivity for online learning during school closures; (4) Increasing pressure on schools and school systems that remain open, school closures may burden schools as parents tend to direct their children to face-to-face schools; (5) Limited social access, given the fact that educational institutions are centers of social activities and human interaction, school closures may prevent teenagers and children from conducting social communication and socialization that are essential for students' learning, development and creativity.

2) Learning Policy during the COVID-19 Pandemic in Indonesia

The Government of Indonesia designated the COVID-19 outbreak as a National Disaster on April 12, 2020 through Presidential Decree No. 12 of 2020 concerning the Determination of Non-Natural Disasters spreading CORONA VIRUS DISEASE 2019 (COVID19) as a National Disaster (Arifin, 2020). Previously, the Government has established a large-scale social restriction policy (PSBB) as a form of government efforts to prevent the spread of COVID19. This policy is regulated through Government Regulation No. 21 of 2020 and further regulated in Regulation of the Minister of Health No. 9 of 2020 (Kemlu, 2020). PSBB is a restriction on certain activities of residents in an area that is suspected of being infected with COVID-19 to prevent its spread (PP No. 21/2020). The implementation of PSBB policy is considered more appropriate and effective than the implementation of Lockdown policy, where access to and out of an infected area is closed and residents are required to be at home or a place provided by the government and prohibited from doing activities outside the home including to fulfill their needs. Meanwhile, in psbb policy, the government seeks to overcome the spread of the virus while providing access to its residents to carry out certain activities especially for the fulfillment of their needs based on the provisions and restrictions set by the government (Herdiana, 2020; Nasruddin \& Haq, 2020). Quoted from the Kompas.com of implementation of PSBB based on Permenkes No.9/2020 covering the disbursement of schools and workplaces, restrictions on religious 
activities, restrictions on activities in public places and facilities (except health care facilities and public facilities for other basic needs), restrictions on social and cultural activities (including all political, sports, entertainment, academic and cultural meetings), and restrictions on other activities specifically related to defense and security aspects (except for the purposes of enforcing state sovereignty, maintaining territorial integrity, and protecting the nation from threats of interference, and realizing security and public order (Mukaromah, 2020)

Since the government implemented social distancing policy, all activities involving mass gatherings are limited, including teaching and learning activities in educational institutions. Face-to-face learning activities are diverted to Distance Learning (PJJ) online and offline to avoid the spread of viruses (Sari et al., 2020). The Government of Indonesia through the Ministry of Education and Culture issued Circular Letter No. 4 of 2020 concerning the Implementation of Education Policy in the Emergency Period of Corona Virus Disease (COVID-19) which is further explained in Circular Letter Sesjen No. 15 of 2020 concerning Guidelines for The Implementation of Learning From Home In The Emergency Period of the Spread of Covid-19. Details of the main points of application of the learning process from home include: (1) The process of distance learning (PJJ) can be done online, semi-online and offline. The learning process is not expected to burden students to complete all curriculum achievements and promote positive patterns of interaction and communication between teachers and parents; (2) PJJ focuses more on life skills education or soft skills, such as life skills in the face of the COVID-19 pandemic; (3) assignment activities vary between regions, educational units, and participants who adjust the experience to their respective interests and conditions including considering the access gap to facilities for PJJ; (4) the results of the learner's learning process can be done by providing qualitative and useful feedback by the teacher without the need to give quantitative value.

3) Character Education

Character is a characteristic inherent in a person and can be seen from the consistency of one's tendency to behave, while the behavior is not independent but integrated with attitudes and values in the environment (Fahmy et al., 2015). according to Hill (2005), character determines a person's way of thinking and acting, a good character is a character who has an inner motivation to do something right according to the standards of behavior in each situation. according to Lickona (2003) character consists in three elements namely, moral knowing, moral feeling, and moral action. Based on these three elements, a person is considered to have good character if he knows things about moral knowledge, has an interest in moral /good things (moral feeling) and doing good things (moral action). These three elements will lead a person to have good habits in thinking, feeling and behaving towards God Almighty, himself, fellow, environment and nation. Further Omeri (2015) adding that character is a combination of morals, ethics and morals. Morals emphasize the quality of individual actions, actions or behaviors that can be seen from good/bad or right/wrong behavior. While ethics gives an assessment of the good or bad behavior of a person based on the norms that apply in a particular society. As for morality, morality is more to the nature of man itself, where basically in man has embedded the belief that good and bad exist. Thus, character education is defined as value education, ethical education, moral education, character education, which aims to develop the ability of learners in making decisions about the good, nurturing the good, and realizing or applying it in daily life wholeheartedly.

Morgenthau (1991) suggests that a great nation is seen from the character of the nation itself. The strength of character of a nation is influenced by the individual character of its society, if the character of the individual in the society 
is strong then the character of the nation will also be strong (Koellhoffer, 2009). So as an important element that determines the strength of a nation, the character of the nation must be instilled in the younger generation as well as agents of national change. Without efforts to internalize and socialize the values of the nation's character, the younger generation will have a weak foundation as well. Therefore, it is very important to give education to the younger generation (Rokhman et al., 2014). Character education is a holistic educational process that connects the moral dimension with the social realm in the lives of learners as the foundation of the formation of a quality generation, able to live independently and have the right principles that can be accounted for. (Raharjo, 2010). In the context of Indonesian education, character education is an education of noble values derived from the culture of the Indonesian nation itself in order to foster the personality of the younger generation (Julaiha, 2014). The Ministry of Education and Culture also made efforts to revolutionize the nation's character through the Character Education Strengthening Movement (GPPK). PPK is an educational movement in schools to strengthen the character of students through harmonization of sports (Ethics), Sports (Aesthetics), Thinking (literacy), and sports (Kinestetis) with public engagement and work between the school, family and society. Character values are grouped into five main characters and will become the basic pillars of character education in Indonesia. These values are (Kemendikbud, 2018):

a. Religious, reflecting faith in the one True God.

b. Nationalists, putting the interests of the nation and the country above the interests of themselves and their groups.

c. Integrity, efforts to make himself as a person who can always be trusted in words, actions, and work.

d. Gotong royong, reflecting the act of appreciating the spirit of cooperation and working together to solve problems together.

e. Independent, independent of others and use energy, mind, time to realize hopes, dreams and ideals.

4) Implementation of Character Education during the COVID-19 Pandemic

Based on research conducted by Rahayu \& Taufiq (2020) The implementation of character education in Mojokerto District precisely at SDN Kranggan 4 Mojokerto during the pandemic went well, despite some obstacles. Some of the things applied by the school in order to instill character education to students during the COVID-19 pandemic include: (1) students doing morning gymnastics activities from home to instill the importance of maintaining health and healthy living; (2) develop a 5S culture (Smile, greeting, greeting, sungkem, and polite) conducted by teachers during online learning with the aim of forming a polite and peace-loving character in students; and (3) instill a culture of discipline shown by the teacher, where the teacher remains present in the school to carry out teaching duties so that students are expected to apply the culture of discipline. The school also involves the role of parents in controlling and monitoring children's activities during the learning process, so it is expected that the activities carried out by the child can be observed and directed.

The COVID-19 pandemic has caused educators to modify their learning plans in such a way that the methods used are precise and easy for students to understand. Online learning should also remain focused on character education, this is not easy for educators considering the current situation that does not allow to monitor the development of the character of learners directly. However, teachers are required to find a solution to this problem. Moreover, many obstacles faced by students, teachers, parents and education lemabaga during 
the implementation of PJJ policies, such as limitations of mastery of technology, inadequate facilities and infrastructure, limited internet access and limited budget for the needs of PJJ (Syah, 2020). What teachers can do is create interesting and fun learning content so that students are comfortable to learn, and can also be varied with independent assignment activities that are able to hone the character of students (Apriyanto et al., 2020). Teachers can also conduct door-to-door or home visit learning system whenever possible so that students can receive materials directly / face-to-face so as to facilitate in absorbing the materials taught. This method utilizes the surrounding environment so as to create meaningful and fun learning for students and teachers can also monitor the development of the character of learners (Putri et al., 2021).

Another thing teachers can do is maintain communication with the parents of students. When learning from home students will be more at home with family, while interaction with teachers online will be very limited so the role of parents in learning in this pandemic is very important. This is because parents act as the main educators in the household. Parents are required to accompany and supervise the child during the learning is still done remotely so that parents must play an active role in creating an effective learning atmosphere so that the child can learn well (Hignasari \& Wijaya, 2020). Parents can work with teachers to provide information about a child's development during online learning (Putria et al., 2020). The active role of parents is one of the supporting factors for the effectiveness of the learning process held at home and no less important plays a role in the formation of the child's character, so parents must also understand the strategies that tapat to educate the child properly and appropriately (Setiawan, 2019). Therefore, good cooperation between parents, educators (teachers), communities and the government (education units) is needed to achieve success in character building.

\section{CONCLUSION}

The ERA of the COVID-19 pandemic has had a considerable impact on various sectors of life, including education. As a result, the learning system is conducted online, character education is also needed for the future interests of the nation. To implement character education during the COVID-19 pandemic, good cooperation between parents, educators (teachers), communities and governments (educational units) is needed to achieve success in character building.

\section{REFERENCES}

Abidah, A., Hidaayatullaah, H. N., Simamora, R. M., Fehabutar, D., \& Mutakinati, L. (2020). The Impact of Covid-19 to Indonesian Education and Its Relation to the Philosophy of "Merdeka Belajar." Studies in Philosophy of Science and Education, 1(1), 38-49. https://doi.org/10.46627/sipose.v1i1.9 Google Scholar

Amanda, R., Birol, I., Bousquet, J., Ingvarsson, P. K., Jansson, S., Jones, S. J. M., Keeling, C. I., MacKay, J., Nilsson, O., \& Ritland, K. (2014). Insights into conifer giga-genomes. Plant Physiology, 166(4), 1724-1732. Google Scholar

Andriani, D. (2017). Pengaruh Gaya Kepemimpinan Transformasional, Budaya Organisasi Dan Lingkungan Kerja Terhadap Kinerja Karyawan PT." $\mathrm{X}^{\prime \prime}$ Sidoarjo. JBMP (Jurnal Bisnis, Manajemen Dan Perbankan), 2(2), 91102. Google Scholar

Ariarni, N., \& Afrianty, T. W. (2017). Pengaruh Perceived Organizational Support terhadap Kinerja Karyawan dengan Employee Engagement sebagai Variabel Intervening (Studi pada Karyawan PT. Pos Indonesia Kota Madiun). Jurnal Administrasi Bisnis, 50(4), 169-177. Google Scholar

Aslam, F. (2020). COVID-19: The Critical 
Importance of Social Distancing and Working from Home. In Preprints 2020 (Issue April, pp. 1-6). https://doi.org/10.20944/preprints20200 4.0078.v1 Google Scholar

Aswin, A. E., \& Rahyuda, A. G. (2017). Pengaruh Perceived Organizational Support Terhadap Organizational Citizenship Behavior Dengan Variabel Kepuasan Kerja Sebagai Mediasi. EJurnal Manajemen, 6(5), 2729-2755. Google Scholar

COVID-19, G. T. (2021). Peta Sebaran COVID-19. Komite Penanganan COVID19 Dan Pemulihan Ekonomi Nasional. Google Scholar

Gallup, A., Gallup, A. M., \& Newport, F. (2006). The Gallup Poll: Public Opinion 2005. Rowman \& Littlefield. Google Scholar

Hair Jr, J. F., Hult, G. T. M., Ringle, C., \& Sarstedt, M. (2016). A primer on partial least squares structural equation modeling (PLS-SEM). Sage publications. Google Scholar

Harter, J. K., Schmidt, F. L., \& Hayes, T. L. (2002). Business-unit-level relationship between employee satisfaction, employee engagement, and business outcomes: a meta-analysis. Journal of Applied Psychology, 87(2), 268. Google Scholar

Herdiana, D. (2020). Implementasi Kebijakan Pembatasan Sosial Berskala Besar (Psbb) Sebagai Upaya Penanggulangan Corona Virus Disease 2019 (Covid-19). Decision: Jurnal Administrasi Publik, 2(2), 1-14. https://doi.org/10.23969/decision.v2i2.2 978 Google Scholar

Intania, E. V. (2020). The role of character education in learning during the COVID19 pandemic Peran pendidikan karakter dalam pembelajaran selama pandemi. Jurnal Penelitian IImu Pendidikan, 13(2), 129-136.

https://doi.org/https://doi.org/10.21831 /jpipfip.v13i2.32979 Google Scholar
Jahroh, W. S., \& Sutarna, N. (2016). Pendidikan Karakter Sebagai Upaya Mengatasi Degradasi Moral. Prosiding Seminar Nasional Inovasi Pendidikan, 395-402. Google Scholar

Surat Edaran Nomor 15 Tahun 2020 Tentang Pedoman Penyelenggaraan Belajar Dari Rumah Dalam Masa Darurat Penyebaran Corona Virus Disease (COVID-19). Google Scholar

Nugraha, B., Wahyuni, L. K., Laswati, H., Kusumastuti, P., Tulaar, A. B., \& Gutenbrunner, C. (2020). COVID-19 pandemic in Indonesia: Situation and challenges of rehabilitation medicine in Indonesia. Acta Medica Indonesiana, 52(3), 299-305. Google Scholar

Organ, D. W. (1994). Personality and organizational citizenship behavior. Journal of Management, 20(2), 465478. Google Scholar

Organ, D. W., Podsakoff, P. M., \& MacKenzie, S. B. (2005). Organizational citizenship behavior: Its nature, antecedents, and consequences. Sage Publications. Google Scholar

Osman, M. E. T. (2020). Global impact of COVID-19 on education systems: the emergency remote teaching at Sultan Qaboos University. Journal of Education for Teaching, 46(4), 463-471. https://doi.org/10.1080/02607476.2020. 1802583 Google Scholar

Owusu-Fordjour, C., Koomson, C. K., \& Hanson, D. (2020). European Journal of Education Studies THE IMPACT OF COVID-19 ON LEARNING -. European Journal of Education Studies, 7(3), 88101.

https://doi.org/10.5281/zenodo.375358 6 Google Scholar

Pertiwi, B. R. (2019). Tinjauan Yuridis Pengangkutan Barang Melaui Laut Dalam Bill Of Lading. Universitas Ahmad Dahlan. Google Scholar

Prawira, J. (2019). Pengaruh Perceived 
Organizational Support Terhadap Employee Performance Melalui Employee Engagement CV Sumo Surya Perkasa di Lombok. Agora, 71 ). Google Scholar

Santika, I. W. E. (2020). Pendidikan Karakter pada Pembelajaran Daring. Indonesian Values and Character Education Journal, 3(1), 8-19. Google Scholar

Sari, W., Rifki, A. M., \& Karmila, M. (2020). Pembelajaran Jarak Jauh Pada Masa Darurat Covid 19. Jurnal MAPPESONA, 1, 12. Google Scholar

Setiawan, O. D., \& Widjaja, D. C. (2018). Analisa pengaruh Employee Engagement Terhadap Kinerja Karyawan dengan Kepuasan Kerja sebagai Variabel Intervening di ShangriLa Hotel Surabaya. Jurnal Hospitality Dan Manajemen Jasa, 6(2). Google Scholar

Sintema, E. J. (2020). Effect of COVID-19 on the performance of grade 12 students: Implications for STEM education. Eurasia Journal of Mathematics, Science and Technology Education, 16(7), 1-6. https://doi.org/10.29333/EJMSTE/7893 Google Scholar

Soegandhi, V. M. (2013). Pengaruh kepuasan kerja dan loyalitas kerja terhadap organizational citizenship behavior pada karyawan PT. Surya Timur Sakti Jatim.
Agora, 1(1), 808-819. Google Scholar

Tjahjaningsih, C. C. E. (2016). Pengaruh Employee Engagement Dan Modal Sosial Terhadap Kinerja Karyawan Dengan OCB (Organizational Citizenship Behaviour) Sebagai Mediasi (Studi pada Bank Jateng Kantor Pusat). Media Ekonomi Dan Manajemen, 30(2). Google Scholar

Tuwu, D. (2020). Kebijakan Pemerintah Dalam Penanganan Pandemi Covid-19. Journal Publicuho, 3(2), 267. https://doi.org/10.35817/jpu.v3i2.12535 Google Scholar

UNESCO. (2020). Distance Learning Solutions. UNESCO. Google Scholar

WHO. (2020). WHO Director-General's opening remarks at the media briefing on COVID-19 - 11 March 2020. World Health Organization. Google Scholar

Wulandari, A. D., \& Yuniawan, A. (2017). Analisis Pengaruh Dukungan Organisasi Dan Pengembangan Karir Terhadap Organizational Citizensip Behavior Dengan Employee Engagement Sebagai Variabel Intervening (Studi Pada Karyawan PDAM Tirta Moedal Kota Semarang). Diponegoro Journal of Management, 6(4), 102-115. Google Scholar

\section{Copyright holder:}

Suwarno, Masruchan, Saparso, and Muhaimin (2021)

First publication right:

Journal of Social Science (JSS)

This article is licensed under:

(c) (i) (?) 